\title{
Summary of Hydrologic Conditions in Kansas, Water Year 2014
}

\section{by Andrew L. Robison}

\section{Hydrologic Conditions in Kansas, Water Year 2014}

The U.S. Geological Survey (USGS) Kansas Water Science Center, in cooperation with Federal, State, and local agencies, maintains a long-term network of hydrologic monitoring gages in the State of Kansas. These include 206 real-time streamgages (herein referred to as gages), 12 real-time reservoir-level monitoring stations, and 32 groundwater monitoring wells. These data and associated analyses, accumulated over time, provide a unique overview of hydrologic conditions and help improve our understanding of Kansas's water resources.

Real-time data are verified throughout the year with regular measurements of streamflow, lake levels, and groundwater levels made by USGS hydrographers (U.S. Geological Survey, 2014a). Yearly hydrologic conditions are determined by comparing statistical analyses of current and historical water year (WY) data for the period of record. A WY is defined as a 12-month period from October 1 through September 30 and is designated by the calendar year in which the period ends. These data are used in protecting life and property, and managing water resources for agricultural, industrial, public supply, ecological, and recreational purposes.

\section{Statewide Precipitation}

Statewide, Kansas received below average precipitation for the third time in 4 water years (National Oceanic and Atmospheric Administration, National Climatic Data Center, 2014). The areas in Kansas that received the lowest percent of normal precipitation in WY 2014 were located in the southeast, south central, and extreme southwest along the Colorado border (fig. 1). Parts of western and northwestern Kansas received generally above-normal levels of precipitation. During WY 2014, the spatial distribution of precipitation resulted in an overall increase of land area classified as abnormally dry and having moderate drought conditions (fig. 2, table 1). At the end of WY 2014, more than 80 percent of the State had abnormally dry conditions or less compared with about 50 percent at the beginning of WY 2014. Even so, with above-normal precipitation in the areas of the State that were driest at the beginning of the year, severe drought conditions subsided. The area with severe and extreme drought conditions decreased from about 32 percent to 20 percent. Overall, Statewide conditions continue to improve from peak drought in August of 2012 when more than 95 percent of the State was under extreme drought conditions (U.S. Drought Monitor, 2014).

\section{Streamflow Conditions and Drainage Basin Runoff}

Streams in Kansas had predominantly normal streamflow conditions during WY 2014 (U.S. Geological Survey, 2014b). Although the northwestern and south-central areas of Kansas began the WY with below normal streamflow conditions (fig. 3), above average rainfall, particularly in the western areas of the
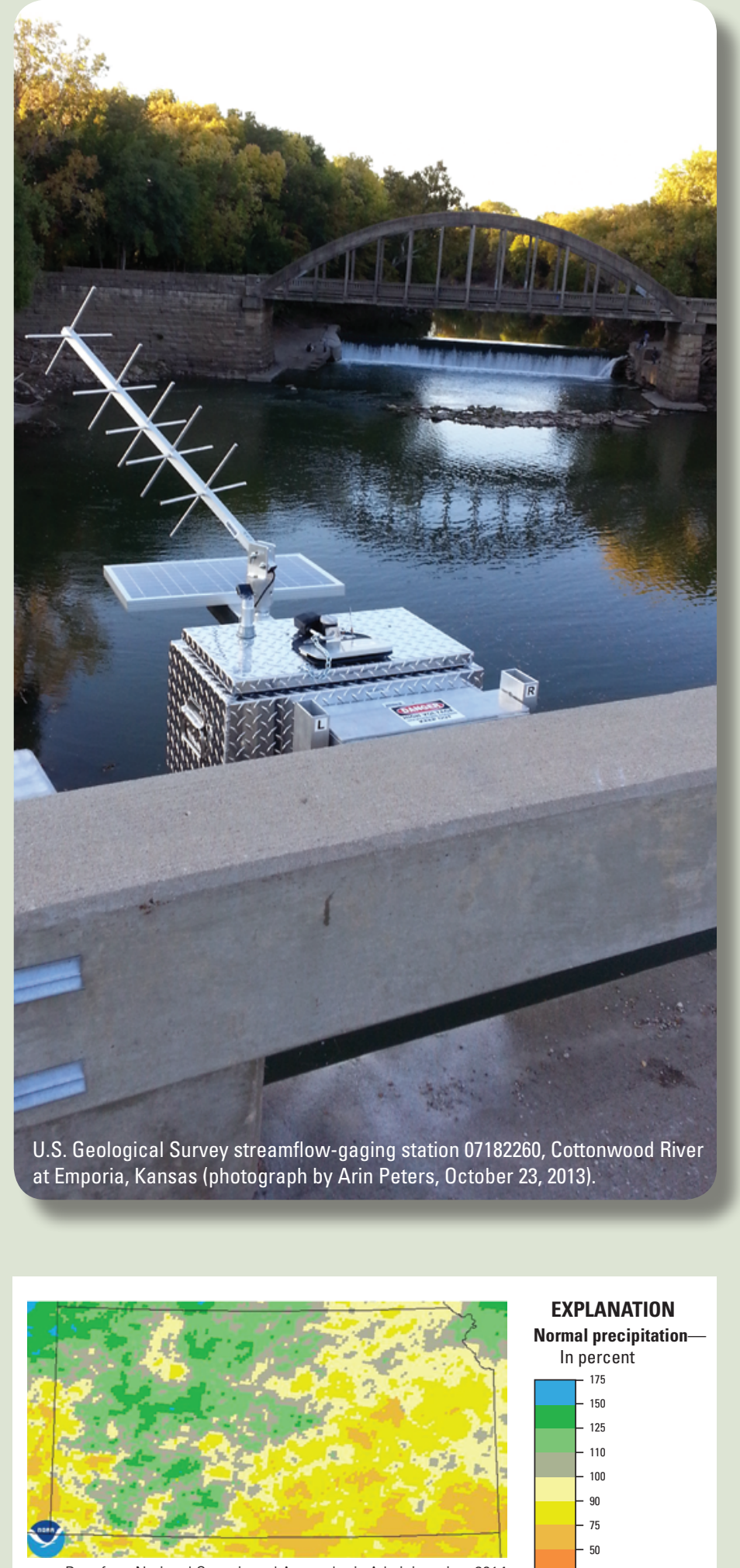

EXPLANATION

Normal precipitationIn percent

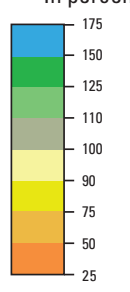

Figure 1. Statewide percent of normal (1981-2010) precipitation for water year 2014. Source: http://water.weather.gov. 


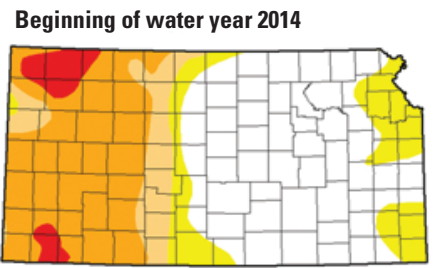

End of water year 2014

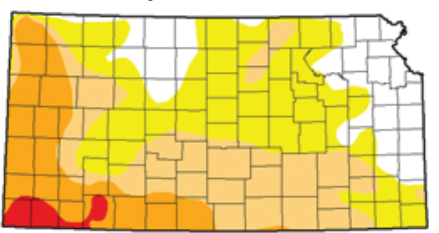

Data from U.S. Monitor, 2014

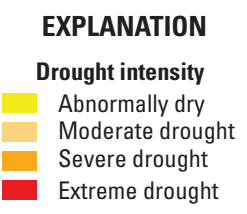

Figure 2. Comparison of statewide drought conditions and intensity between the beginning and end of water year 2014. Source: http:// droughtmonitor.unl.edu/.

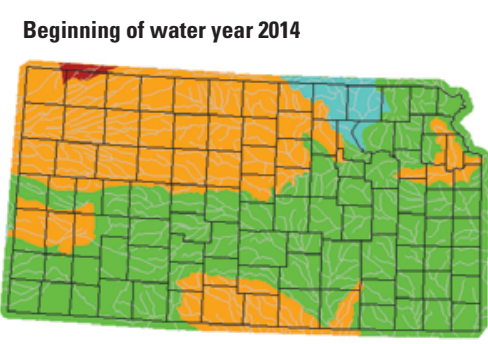

End of water year 2014

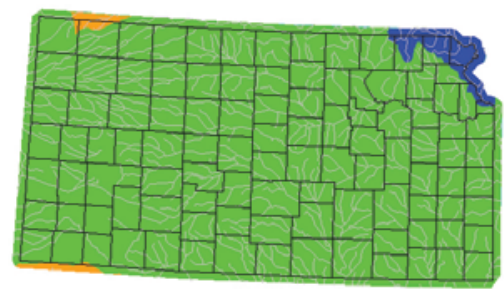

\section{EXPLANATION}

Streamflow precentile classes

Greater than 90-Much above normal

75 to 90-Above normal

25 to $74-$ Normal

10 to 25 - Below normal

Less than 10-Much below normal

Figure 3. Comparison of streamflow conditions at the beginning and end of water year 2014. Source: http://waterwatch.usgs. gov/.

State where drought conditions were previously the most intense, led to increased streamflow. By the end of WY 2014, streamflow conditions in almost the entire State were classified as normal (U.S. Geological Survey, 2014). An exception to this trend was streamflow in the Missouri River Basin in northeastern Kansas, which was much above normal at the end of WY 2014.

Runoff, or streamflow per unit area, is a good indicator of precipitation and streamflow conditions for a given basin (Langbein and Iseri, 1960). Statewide runoff for WY 2014 was the third lowest in the last 47 years (U.S. Geological Survey, 2014b). Quarterly maps of drainage basin runoff can provide insight into the variability of hydrologic conditions throughout a WY (fig. 4) including development or improvement of drought conditions (fig. 2). Examining these quarterly runoff percentiles for Kansas in WY 2014 reveals an east-west divide. Runoff in the western half of the State was below normal or much below
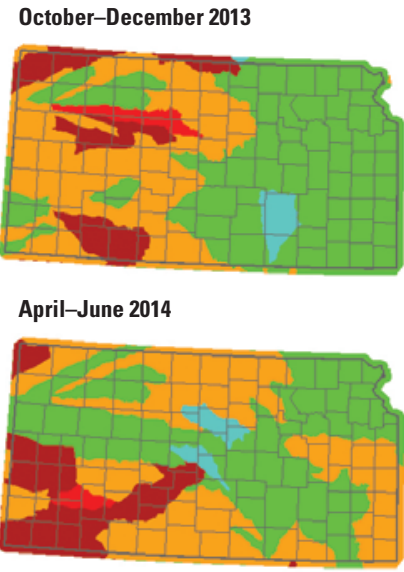

\section{EXPLANATION}

Runoff precentile classes

Greater than $90-$ Much above normal 75 to 90 -Above normal 25 to 74 -Normal
January-March 2014

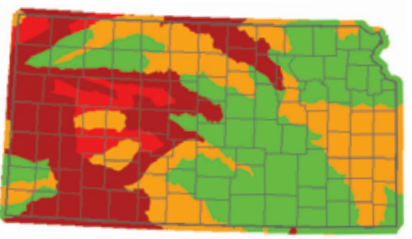

July-September 2014

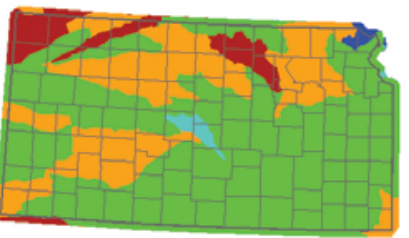

10 to $24-$ Below normal Less than 10-Much below normal Lowest
Figure 4. Quarterly runoff percentiles by drainage basin, for water year 2014. Source: http://waterwatch.usgs.gov/.

normal for most of WY 2014, including some of the lowest runoff percentiles calculated since 1940. Meanwhile, runoff percentiles in the eastern half of the State were predominately normal or below normal. Runoff is not solely dependent on precipitation inputs to an area, as infiltration of precipitation and streamflow into the ground or storage in reservoirs can prevent water from leaving a drainage basin; thus, while precipitation in the western half of the State was above average, increased groundwater storage and water storage in reservoirs likely prevented increased runoff.

\section{Reservoirs}

Over the course of WY 2014, 9 of the 12 reservoirs monitored by the USGS in Kansas increased water storage (table 2); that is, the amount of water contained within the reservoirs was greater at the end of WY 2014 than at the beginning. The lower water levels observed in the reservoirs at the beginning of the water year was a consequence of the extended drought the State has experienced in the previous few years. By holding streamflow within reservoirs, less water is released downstream, and ultimately less runoff from the State is generated. The storage of water in gaged reservoirs during WY 2014 $(29,900 \mathrm{ac}-\mathrm{ft})$ was equivalent to 0.26 percent of median annual runoff from the State (10.7 million ac-ft) (U.S. Geological Survey, 2014a). This is a contributing factor to the low runoff observed during WY 2014 as described in "Streamflow Conditions and Drainage Basin Runoff."

Table 1. Percent areal coverage of drought conditions in the state of Kansas at the beginning and end of water year 2014.

[Data from U.S. Drought Monitor, 2014]

\begin{tabular}{lccccc}
\hline & None & $\begin{array}{c}\text { Abnormally } \\
\text { dry }\end{array}$ & $\begin{array}{c}\text { Moderate } \\
\text { drought }\end{array}$ & $\begin{array}{c}\text { Severe } \\
\text { drought }\end{array}$ & $\begin{array}{c}\text { Exceptional } \\
\text { drought } \\
\text { drought }\end{array}$ \\
\hline Start of water year 2014 & 46.1 & 53.9 & 40.3 & 31.9 & 3.96 \\
End of water year 2014 & 18.5 & 81.5 & 49.1 & 19.5 & 2.37 \\
\hline
\end{tabular}


Table 2. Change in storage during water year 2014 in 12 reservoirs with complete records monitored by the U.S. Geological Survey.

[Percent change in storage is calculated in reference to the initial content for water year 2014]

\begin{tabular}{|c|c|c|c|}
\hline $\begin{array}{l}\text { Station } \\
\text { number }\end{array}$ & $\begin{array}{l}\text { Station name } \\
\text { (fig. 6) }\end{array}$ & $\begin{array}{l}\text { Change in } \\
\text { storage } \\
\text { (acre-feet) }\end{array}$ & $\begin{array}{c}\text { Change in } \\
\text { storage } \\
\text { (percent) }\end{array}$ \\
\hline 06857050 & Milford Lake near Junction City, Kansas & 5,000 & 1.25 \\
\hline 06861500 & Cedar Bluff Reservoir near Ellis, Kansas & 6,900 & 12.2 \\
\hline 06865000 & Kanopolis Lake near Kanopolis, Kansas & 3,900 & 7.08 \\
\hline 06868100 & Wilson Lake near Wilson, Kansas & $-19,000$ & -9.74 \\
\hline 06886900 & $\begin{array}{l}\text { Tuttle Creek Lake near Manhattan, } \\
\text { Kansas }\end{array}$ & 17,000 & 6.05 \\
\hline 06890898 & Perry Lake near Perry, Kansas & 16,000 & 7.66 \\
\hline 06891478 & Clinton Lake near Lawrence, Kansas & 17,100 & 18.0 \\
\hline 06910997 & Melvern Lake near Melvern, Kansas & 10,000 & 7.46 \\
\hline 06912490 & Pomona Lake near Quenemo, Kansas & 0 & 0 \\
\hline 06914995 & Hillsdale Lake near Hillsdale, Kansas & 4,100 & 5.96 \\
\hline 07140885 & $\begin{array}{l}\text { Horsethief Reservoir near Jetmore, } \\
\text { Kansas }\end{array}$ & 930 & 78.2 \\
\hline 07144790 & Cheney Reservoir near Cheney, Kansas & $-8,000$ & -4.85 \\
\hline \multicolumn{2}{|c|}{ Total } & 29,900 & 3.15 \\
\hline
\end{tabular}

One Kansas reservoir with noteworthy dynamics during WY 2014 is Clinton Lake (06891478). The water-surface elevation at Clinton Lake reached a record low of 870.99 feet on April 10, 2014, which is the lowest since the reservoir was first filled in 1981 (fig. 5; U.S. Geological Survey, 2014a). As precipitation in the Clinton Lake drainage basin increased later in WY 2014, particularly during June, enough water was supplied for the reservoir to fill above the conservation pool elevation. The conservation pool elevation is the range of elevations within which water from the reservoir can be freely released for downstream uses. As such, achieving this level is critical for the reservoir to function effectively.

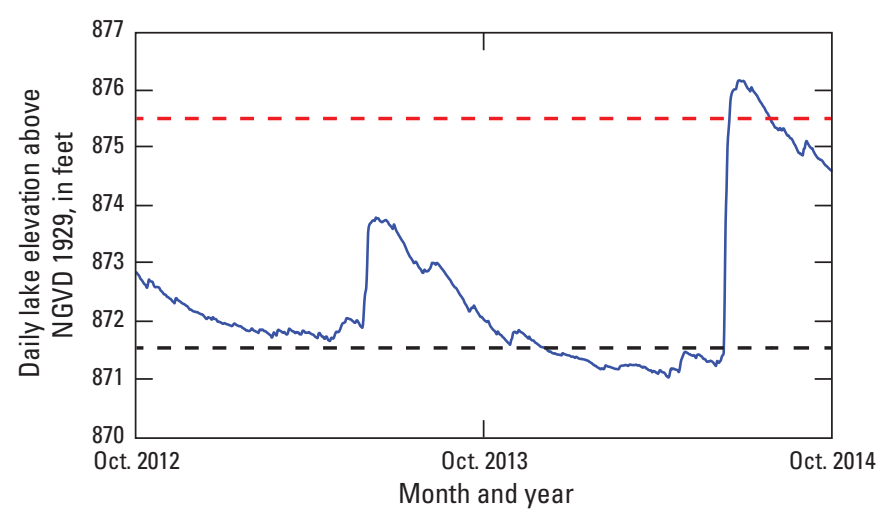

EXPLANATION

_ Daily lake elevation above National Geodetic Vertical Datum of 1929 (NGVD 29)

- - Conservation pool elevation

- Previous low record

Figure 5. Water-surface elevation for Clinton Lake near Lawrence, Kansas, during water years 2013-14.

\section{Streamflow Conditions at Selected Streamgages, Water Years 2013 and 2014}

Streamflow conditions at four selected streamgages are summarized by comparing the 7-day average streamflow during WY 2013 and 2014 to the historical average 7-day streamflow percentile (fig. 6). Streamflow conditions at the selected streamgages reflect the different precipitation patterns and hydrologic conditions in different parts of Kansas.

06873000 South Fork Solomon River above Webster Reservoir, Kansas.-The gage on the South Fork Solomon River above Webster Reservoir (fig. 7) includes a drainage basin of 1,040 miles squared $\left(\mathrm{mi}^{2}\right)$ entirely in northwestern Kansas. Streamflow conditions at the gage during most of WY 2013 and early WY 2014 were below normal as a result of severe drought, but above normal precipitation during the second half of WY 2014 increased flow to normal and above normal ranges. This pattern of increased flow was typical in northwestern Kansas where drought conditions improved during WY 2014.

06889200 Soldier Creek near Delia, Kansas.-The Soldier Creek basin encompasses an area of about $290 \mathrm{mi}^{2}$ before entering the Kansas River. During the first half of WY 2013, streamflow recorded by the Soldier Creek gage near Delia, Kans. (fig. 7), set several record low 7-day averages. Precipitation during the second half of WY 2013 and during WY 2014 broke this trend. Streamflow conditions improved to normal and below normal by April of WY 2013. No record 7-day average lows were set in WY 2014, and streamflow conditions much below average were infrequent. Streamflow conditions similar to this site were common in northeastern Kansas during WY 2014 because drought conditions were mild or absent.

07157500 Crooked Creek near Englewood, Kansas.-The gage near Englewood on Crooked Creek (fig. 7) includes a drainage basin of $1,157 \mathrm{mi}^{2}$ and has been in service for 71 years. In WY 2013, streamflow conditions were predominately much below normal, setting or tying several record lows. This pattern continued throughout much of WY 2014, but with early summer precipitation, streamflow conditions improved to normal for most of the remainder of WY 2014, following a similar trajectory of drought improvement in the southwest region of the State.

07183500 Neosho River near Parsons, Kansas.-The Neosho River, a tributary of the Arkansas River, drains an area more than 5,000 $\mathrm{mi}^{2}$ in southeastern Kansas before flowing into Oklahoma. At the gage on the Neosho River near Parsons, Kans. (fig. 7), streamflow conditions were much above normal and much below normal during WY 2013 and WY 2014. Most of streamflow conditions were observed in the normal range. While precipitation in this region was below normal for WY 2014, drought conditions in southeastern Kansas remained relatively mild. The hydrologic patterns at Parsons, Kans., indicate how relatively normal hydrological conditions persisted in southeastern Kansas during WY 2014.

\section{Summary}

Drought conditions continued to subside during WY 2014 from the most severe period during the summer of 2012. While most of the State remained under abnormally dry conditions 

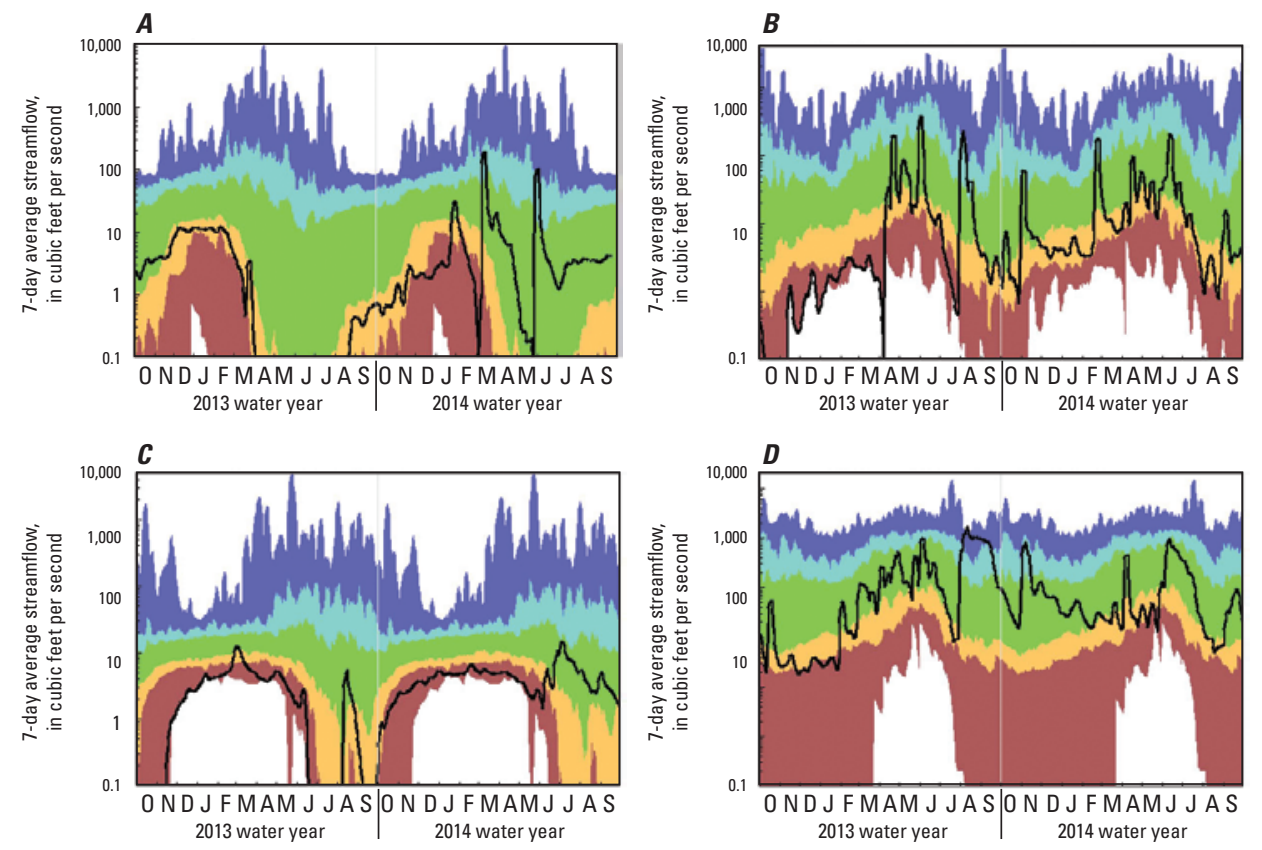

\section{EXPLANATION \\ Streamflow condition based on historical average 7-day streamflow percentile ranges \\ Greater than 90-Much above normal \\ 75 to 90 -Above normal \\ 25 to 74 -Normal \\ 10 to $24-$ Below normal \\ Less than 10-Much below normal}

7-Day average streamflow

Figure 6. Hydrographs showing streamflow condition by comparing the 7-day average streamflow for four selected streamgages, in Kansas for water years 2013-14. A, 06873000 South Fork Solomon River above Webster Reservoir, Kansas; B, 06889200 Soldier Creek near Delia, Kansas; C, 07157500 Crooked Creek near Englewood, Kansas; and D, 07183500 Neosho River near Parsons, Kansas. Source: http:// waterwatch.usgs.gov/.

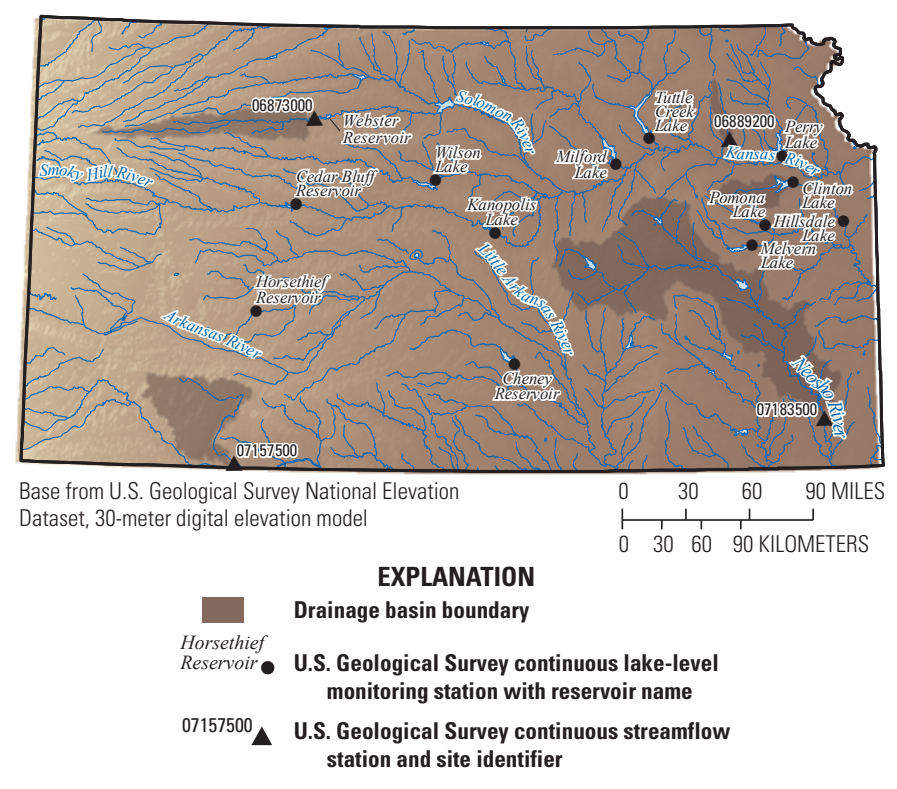

Figure 7. Locations of drainage basins, streamgages, and reservoirs, Kansas, water year 2014.

during WY 2014, the size of the area classified as severe drought decreased. This resulted primarily from above-normal precipitation in the north and west areas of the State where drought conditions have been the most intense in the last few years. In eastern Kansas, precipitation was generally below normal during WY 2014, but there was enough to increase water storage in most of the major reservoirs. The capturing of precipitation in aquifers, reservoirs, and other impoundments that began during WY 2014 with below normal levels of precipitation resulted in the third lowest statewide runoff in the last 47 years.

\section{References Cited}

Langbein, W.B., and Iseri, K.T., 1960, General introduction and hydrologic definitions: U.S. Geological Survey Water-Supply Paper 1541-A, 29 p.

National Oceanic and Atmospheric Administration, National Climatic Data Center, 2014, National temperature and precipitation maps: accessed December 3, 2014, at http://www.ncdc. noaa.gov/temp-and-precip/maps.php.

National Oceanic and Atmospheric Administration, National Weather Service, 2014, Advanced hydrologic prediction service-2015 precipitation maps for Kansas: accessed December 3, 2014, at http://water.weather.gov/precip/.

U.S. Drought Monitor, 2014, Map service-Kansas drought monitor: accessed December 3, 2014, at http://droughtmonitor.unl.edu/.

U.S. Geological Survey, 2014a, Water data for Kansas: accessed December 3, 2014, at http://waterdata.usgs.gov/ks/nwis/.

U.S. Geological Survey, 2014b, Water Watch-Current water resources in Kansas: accessed December 3, 2014, at http:// waterwatch.usgs.gov/.

\section{For more information, contact:}

Director, USGS Kansas Water Science Center 4821 Quail Crest Place

Lawrence, Kansas 66049

(785) 842-9909

http://ks.water.usgs.gov 